Article

\title{
Riluzole Oral Suspension for the Treatment of Amyotrophic Lateral Sclerosis: Texture and Compatibility with Food Thickeners Evaluation
}

\author{
Giuseppe Colombo *(1), Roberta Artico and Daniele Barbareschi \\ Pharmaceutical Technology Laboratory, Italfarmaco SpA, 20126 Milan, Italy; \\ r.artico@italfarmaco.com (R.A.); d.barbareschi@italfarmaco.com (D.B.) \\ * Correspondence: giuseppe.colombo@italfarmaco.com; Tel.: +39-02-64433011
}

Received: 30 July 2020; Accepted: 14 August 2020; Published: 19 August 2020

\begin{abstract}
Riluzole $5 \mathrm{mg} / \mathrm{mL}$ oral suspension is the only licensed liquid medicine to treat Amyotrophic Lateral Sclerosis (ALS) orally. As more than $80 \%$ of ALS patients develop dysphagia, an oral liquid formulation provides an important therapeutic option. The Riluzole $5 \mathrm{mg} / \mathrm{mL}$ oral suspension is administered by means of the graduated oral dosing syringe included in the medicine package. Its concentration $(5 \mathrm{mg} / \mathrm{mL})$ is consistent with a small and easy to measure volume $(10 \mathrm{~mL})$ to deliver the prescribed 50-mg dose twice daily. This work had a dual objective. The first was to evaluate the texture of the Riluzole $5 \mathrm{mg} / \mathrm{mL}$ oral suspension according to the International Dysphagia Diet Standardisation Initiative (IDDSI) flow test. Results of this experiment indicated that Riluzole $5 \mathrm{mg} / \mathrm{mL}$ oral suspension would basically fall under the "mildly thick" IDDSI descriptors. This is an important feature because thick fluids facilitate a safer swallow in patients with dysphagia. As a second objective, we evaluated for scientific purposes the compatibility of Riluzole $5 \mathrm{mg} / \mathrm{mL}$ oral suspension with some of the most common food thickeners available on the market. Intimate mixtures of the Riluzole $5 \mathrm{mg} / \mathrm{mL}$ oral suspension with thickeners were evaluated for appearance, $\mathrm{pH}$, Riluzole assay and Riluzole related substances immediately after preparation and after two hours at room temperature. Riluzole $5 \mathrm{mg} / \mathrm{mL}$ oral suspension resulted to be compatible with all the marketed thickeners tested.
\end{abstract}

Keywords: ALS; dysphagia; Riluzole oral suspension; HPLC; patient compliance; liquid formulation

\section{Introduction}

Amyotrophic lateral sclerosis (ALS) is a progressive neurodegenerative disease affecting nerve cells in the brain and the spinal cord. These cells are needed to keep our muscles moving. When the lateral area of the spinal cord degenerates, there is a sclerosis in that region and, when the motor neurons die, the brain cannot control muscle movement anymore. With voluntary muscle action progressively affected, people may lose the ability to speak, eat, move and breathe. The disease leads to paralysis and death typically within 2-5 years following the of diagnosis, although at least 1 in 10 people live more than 10 years after experiencing the signs of the disease. Generally, death occurs because of respiratory failure, aspiration pneumonia, malnutrition, and dehydration [1-3].

Dysphagia is the medical term for swallowing difficulties. This impairment leads to malnutrition, dehydration, weight loss, functional decline and fear of eating and drinking, as well as a decrease in the quality of life [4] compromising safety and adherence to treatments [5]. Swallowing problems are reported to affect approximately $60-75 \%$ of people in care homes and $22 \%$ of the world population over the age of 55 years [6]. Dysphagia is present in more than $50 \%$ of ALS patients at onset according clinical practice evidence (94.7\% bulbar onset patients and $35.2 \%$ spinal onset patients) and over $80 \%$ will 
develop this condition and/or need enteral feeding in the later stages of the disease [2,7]. Aspiration and choking are major concerns with dysphagia. Because of aspiration, the foods or liquids pass into the lungs, which have minimal defence systems against boluses containing bacteria. Repeated aspiration of foods and liquids is associated with pneumonia. Choking occurs when either the tongue cannot create an appropriate size bolus before swallowing or the throat muscles are too weak to propel boluses into the oesophagus, or both [8]. Recently, an expert group proposed a guideline for the management of drug administration to patients with swallowing issues [9]. According to the algorithm presented in this document, the availability of a liquid or dispersible product is the first step to look at when the swallowing difficulty is likely to be long term and the oral route is appropriate.

There is no cure for ALS. There are only two drugs licensed for use in the management of ALS, Riluzole and Edaravone (marketed as Radicava). Riluzole is approved in the European Union and US. Rilutek ${ }^{\circledR}$ has been available on the US market since 1995. It is supplied as 50-mg, film-coated tablets. The recommended dose is $50 \mathrm{mg}$ twice daily. The overall survival increase in ALS patients treated with Riluzole is supported by more than 20 years of clinical practice $[7,10,11]$. Riluzole has been demonstrated to prolong overall survival up to 21 months and the time to need enteral nutrition and ventilatory support [11]. According to guidelines, Riluzole has to be used, as soon as possible, from ALS diagnosis and until the end of life [12-14]. More recently, a novel, patented oral liquid presentation of Riluzole $5 \mathrm{mg} / \mathrm{mL}$ oral suspension has been introduced. This is marketed as Teglutik ${ }^{\circledR}$ in Italy, Spain, France, UK, and other European countries and as Tiglutik ${ }^{\mathrm{TM}}$ in the US. It is a $50 \mathrm{mg} / 10 \mathrm{~mL}(5 \mathrm{mg} / \mathrm{mL})$ slightly brown, opaque, homogeneous suspension supplied in a $300 \mathrm{~mL}$, multiple-dose amber bottle, closed with child-resistant, tamper-evident screw caps. In a bioequivalence study between the oral suspension and tablets, the total exposure of the drug was equivalent [15]. The recommended dosage of Riluzole suspension is $50 \mathrm{mg}(10 \mathrm{~mL})$ taken orally twice daily, every $12 \mathrm{~h}$.

Riluzole oral suspension was developed by Italfarmaco S.p.A., Italy. It was designed to specifically overcome the challenges of the disease-related dysphagia in ALS. Riluzole is a well-known and stable molecule, the relevant USP and EP monographs do not require particular storage conditions and indicate suitable analytical methods for assessing its quality and stability. Riluzole is a lipophilic drug substance with a low aqueous solubility and an aqueous solution formulation of Riluzole is therefore not feasible [15]. The drug is very slightly soluble in water at neutral $\mathrm{pH}(\sim 0.3 \mathrm{mg} / \mathrm{mL}$ at $\mathrm{pH}$ 7), thus it is suitable for the development of a liquid formulation in the form of an oral suspension [15]. The suspension was formulated according to the "flocculation in a structured vehicle" approach, $[15,16]$ meaning that optimum physical stability and appearance is obtained, due to both floc formation, resulting in an easily re-dispersible system, and shear-thinning properties, i.e., apparent viscosity is high upon standing but decreases upon shaking. The suspension is readily administered by means of the graduated oral dosing syringe included in the medicine package. Its concentration $(5 \mathrm{mg} / \mathrm{mL})$ is consistent with a small and easy to measure volume $(10 \mathrm{~mL})$ to deliver the prescribed $50 \mathrm{mg}$ dose twice daily. This provides an opportunity for more accurate dosing and enhanced patient compliance [17]. In addition, the suspension potentially allows patients to continue Riluzole oral administration for longer.

Dysphagia in ALS patients increases with the progression of the disease and, prior to passing to an enteral nutrition, there is an intermediate phase where the patients are fed with liquid food made viscous and consistent up to a gel with thickening agents.

One of the most common methods to manage dysphagia is the use of thickened liquids as they flow more slowly, allowing the patients time to coordinate safe swallowing, thus helping prevent aspirations [18-20].

The use of texture-modified foods and thickened liquids has become a cornerstone of clinical practice to address dysphagia (swallowing impairment). The principle behind this pervasive practice arises from the assumption that modifying the properties of normal foods and liquids will make them easier and safer to swallow. In the case of liquids, it is widely accepted that thin liquids (such as water) pose safety challenges for people with dysphagia because they flow quickly. The speed of bolus 
flow from the mouth into the pharynx may be sufficiently fast that it does not provide enough time for the person to engage airway closure before the bolus arrives at the entrance to the larynx and airway. Thickened liquids are frequently recommended with the goal of slowing down the flow of liquids to allow more time for airway closure. Conversely, very thick liquids and solid food materials may require greater strength in terms of the tongue propulsive forces that are used to drive material through the oropharynx. If a person has reduced tongue strength or reduced pharyngeal muscle strength, this is felt to constitute a risk for residues to remain behind in the recesses of the pharynx after a swallow. Similarly, solid foods that require chewing may prove challenging for people with dental issues or weakness in the masticatory muscles. An alteration of the properties of solid foods (by dicing, chopping, mincing or pureeing) is a common approach to making these materials easier for oral processing and swallowing [18].

The widespread use of texture modification as a clinical intervention has created a need to establish clear terminology to describe the target consistencies that are recommended for patients with dysphagia [18].

The International Dysphagia Diet Standardisation Initiative (IDDSI) is a global standard with terminology and definitions to describe texture modified foods and thickened fluids used for individuals with dysphagia of all ages, in all care settings, and for all cultures [21].

In view of the IDDSI-recognized importance, we considered it appropriate to evaluate the Riluzole suspension thickness according to the IDDSI instructions. IDDSI chose a gravity flow test using a $10 \mathrm{~mL}$ syringe, as a simple, easy to use, practical objective measure to classify drinks based on their rate of flow [21].

The aim of this work is to evaluate the texture of Riluzole $5 \mathrm{mg} / \mathrm{mL}$ oral suspension according to the IDDSI flow test and to evaluate its chemical compatibility with some of the most common food thickeners available on the market.

\section{Materials and Methods}

\subsection{Materials}

Riluzole $5 \mathrm{mg} / \mathrm{mL}$ oral suspension was made available by Italfarmaco SpA (Milan, Italy). Riluzole USP reference standard (USP catalog \#1604337) was purchased commercially.

The following common food thickening agents available on the market were kindly donated by the relevant vendor:

- Nutilis Powder (Nutricia, Zutemer, Netherlands)

- Nutilis Clear (Nutricia)

- $\quad$ RESOURCE ${ }^{\circledR}$ ThickenUp ${ }^{\mathrm{TM}}$ (Nestlé Health Science, Vevey, Switzerland)

- $\quad$ Fresubin ${ }^{\circledR}$ Clear Thickener (Fresenius Kabi, Bad Humboldt, Germany)

- $\quad$ THICK \& EASY' Instant Food Thickener (Fresenius Kabi)

- Milli-Q grade water, analytical grade solvents/reagents (Acetonitrile, Trifluoroacetic acid, Ethanol) analytical grade laboratory glassware, disposable plastic syringes and $0.45-\mu \mathrm{m}$ hydrophilic PTFE syringe filters were used.

\subsection{Methods}

\subsubsection{IDDSI Flow Test (Drink Testing Methods)}

The IDDSI flow test (Drink Testing Methods) was conducted at room temperature on two batches of Riluzole $5 \mathrm{mg} / \mathrm{mL}$ oral suspension by two different operators in triplicate ( 3 different syringes, 3 determinations for each syringe for each batch of suspension by using "fresh" suspension each time). According to the IDDSI flow test, a 10-mL Luer tip hypodermic syringes with a length of the 10-mL scale $=61.5 \mathrm{~mm}$ was used $\left(\right.$ BD Plastipak ${ }^{\mathrm{TM}} 10-\mathrm{mL}$ Luer tip syringe; Graduation: 0.5-mL; code REF 308027, Becton, Dickinson and Company, Franklin Lakes, NJ, USA). The syringe was held vertically tip 
down by keeping the nozzle firmly closed with a finger and precisely filled with Riluzole $5 \mathrm{mg} / \mathrm{mL}$ oral suspension up to the 10-mL mark. The nozzle was released for exactly $10 \mathrm{~s}$, measured by means of a certified chronometer (HANHART Profil 1, Diessenhofen, Switzerland) and then immediately closed with finger. The volume of liquid $(\mathrm{mL})$ remaining into the syringe after $10 \mathrm{~s}$ was visually determined and reported. This volume is determining the thickness level of the liquid according to the IDDIS descriptors for drinks as follows: 0-1 mL (level 0, "thin"); 1-4 mL (level 1, "slightly thick"); 4-8 mL (level 2, "mildly thick"); 8-10 mL (level 3, "moderately thick"); $10 \mathrm{~mL}$ (level 4, "extremely thick") [21].

2.2.2. Preparation of Samples for the HPLC Analyses of Riluzole $5 \mathrm{mg} / \mathrm{mL}$ Oral Suspension-Thickener Mixtures

Based on the label instructions of each thickener, reported in Table 1, the amounts of thickening agents to be added were accordingly calculated as the amount required to modify the consistency of a volume corresponding to $2 \mathrm{~g}$ of Riluzole $5 \mathrm{mg} / \mathrm{mL}$ oral suspension (amount of suspension needed for HPLC testing sample preparation) in order to obtain the stage 3 consistency (pudding). This is the upper level for thickened fluid of the BDA/RCSLT (British Dietetic Association/Royal College of Speech \& Language Therapists) descriptors for texture modification of foods and fluids [22]. Although this terminology was going to be replaced, as of April 2019, to adopt the IDDSI framework [23], the terms "Stage 3" and "pudding" were still reported in the leaflets of the commercial thickening agents under evaluation. Regardless of the terminology, the amounts of thickeners mixed with Riluzole $5 \mathrm{mg} / \mathrm{mL}$ oral suspension corresponded to their highest suggested quantity. Therefore, this is the worst case to evaluate the chemical compatibility with Riluzole $5 \mathrm{mg} / \mathrm{mL}$ oral suspension. The compositions of the Riluzole $5 \mathrm{mg} / \mathrm{mL}$ oral suspension-thickener mixtures are reported in Table 2.

Table 1. Instruction for use of thickening agent.

\begin{tabular}{|c|c|c|c|}
\hline Thickening Agent & Stage 1 (Syrup) & Stage 2 (Custard) & Stage 3 (Pudding) \\
\hline Nutilis Powder & $2-3$ scoops $^{(1)}$ per $200 \mathrm{~mL} \mathrm{H}_{2} \mathrm{O}$ & 3-4 scoops per $200 \mathrm{~mL} \mathrm{H}_{2} \mathrm{O}$ & 4-5 scoops per $200 \mathrm{~mL} \mathrm{H}_{2} \mathrm{O}$ \\
\hline Nutilis Clear & 1 scoop $^{(1)}$ per $200 \mathrm{~mL} \mathrm{H}_{2} \mathrm{O}$ & 3 scoops per $200 \mathrm{~mL} \mathrm{H}_{2} \mathrm{O}$ & 6 scoops per $200 \mathrm{~mL} \mathrm{H}_{2} \mathrm{O}$ \\
\hline RESOURCE ${ }^{\circledR}$ ThickenUp $p^{\mathrm{TM}}$ & $\begin{array}{l}1 \text { brimming spoon }{ }^{(2)} \text { per } \\
100 \mathrm{~mL} \mathrm{H}_{2} \mathrm{O}\end{array}$ & $\begin{array}{l}1.5 \text { brimming spoons per } \\
100 \mathrm{~mL} \mathrm{H}_{2} \mathrm{O}\end{array}$ & $\begin{array}{l}2 \text { brimming spoons per } \\
\qquad 100 \mathrm{~mL} \mathrm{H}_{2} \mathrm{O}\end{array}$ \\
\hline Fresubin ${ }^{\circledR}$ Clear Thickener & $\begin{array}{l}1 \text { levelled scoop }{ }^{(3)} \text { per } \\
100 \mathrm{~mL} \mathrm{H}_{2} \mathrm{O}\end{array}$ & $\begin{array}{l}3 \text { levelled scoops per } \\
100 \mathrm{~mL} \mathrm{H}_{2} \mathrm{O}\end{array}$ & $\begin{array}{l}6 \text { levelled scoops per } \\
100 \mathrm{~mL} \mathrm{H}_{2} \mathrm{O}\end{array}$ \\
\hline $\begin{array}{l}\text { THICK \& EASY }{ }^{\mathrm{TM}} \text { Instant } \\
\text { Food Thickener }\end{array}$ & 1 scoop $^{(4)}$ per $100 \mathrm{~mL} \mathrm{H}_{2} \mathrm{O}$ & 1.5 scoops per $100 \mathrm{~mL} \mathrm{H}_{2} \mathrm{O}$ & 2 scoops per $100 \mathrm{~mL} \mathrm{H}_{2} \mathrm{O}$ \\
\hline
\end{tabular}

Table 2. Compositions of Riluzole $5 \mathrm{mg} / \mathrm{mL}$ oral suspension-thickener mixtures.

\begin{tabular}{cccccc}
\hline Composition & $\begin{array}{c}\text { Nutilis } \\
\text { Powder (A) }\end{array}$ & $\begin{array}{c}\text { Nutilis Clear } \\
\text { (B) }\end{array}$ & $\begin{array}{c}\text { RESOURCE }^{\circledR} \\
\text { ThickenUp }^{\text {TM }} \text { (C) }\end{array}$ & $\begin{array}{c}\text { Fresubin } \\
\text { Thickener (D) }\end{array}$ & $\begin{array}{c}\text { THICK \& EASYTM Instant } \\
\text { Food Thickener (E) }\end{array}$ \\
\hline $\begin{array}{c}\text { Riluzole } 5 \mathrm{mg} / \mathrm{mL} \\
\text { oral suspension (g) }\end{array}$ & 2.0 & 2.0 & 2.0 & 2.0 & 2.0 \\
Thickening agent (g) & 0.174 & 0.2088 & 0.1566 & 0.1827 & 0.1566 \\
\hline
\end{tabular}

Description of mixture preparation process: manually shake the suspension for at least $30 \mathrm{~s}$ by rotating the bottle by $180^{\circ}$. Withdraw the suspension using the graduated oral dispenser (syringe) included in the Riluzole $5 \mathrm{mg} / \mathrm{mL}$ oral suspension packaging. Weigh exactly the amount of thickening agent (powder) according to Table 2 and transfer into a 50-mL volumetric flask. Add into the same flask $2 \mathrm{~g}$ of suspension exactly weighed, trying to wet the powder of the thickening agent as much as possible. Shake by vortexing for about $1 \mathrm{~min}$, to allow a complete hydration of the powder. Then add $10 \mathrm{~mL}$ of dilution solvent (Ethanol 60\% v/v in Water) and shake by vortexing for at least $1 \mathrm{~min}$. Repeat the vortexing operation by adding another $10 \mathrm{~mL}$ of solvent. Add solvent up to about $45 \mathrm{~mL}$ and sonicate for $20 \mathrm{~min}$. Cool down the dispersion and bring to volume with dilution solvent. Use this sample for Riluzole related substances analysis. Then, withdraw $4 \mathrm{~mL}$ and dilute to $10 \mathrm{~mL}$ in a volumetric flask with dilution solvent. Use this sample for Riluzole assay analysis (Riluzole concentration $\approx 70 \mu \mathrm{g} / \mathrm{mL}$ ). 
Filter all solutions through a $0.45-\mu \mathrm{m}$ PTFE filter, disregarding the first $\mathrm{mL}$ and analyse. Repeat the preparation by maintaining the thickened Riluzole suspension (combination of thickening agent plus suspension) into the flask for two $\mathrm{h}$ at room temperature (normal ambient laboratory temperature and light conditions) before dilution with solvent. Perform the test in duplicate for both conditions (immediate dilution with solvent and after two hours).

Two control samples were prepared as well: the first was Riluzole $5 \mathrm{mg} / \mathrm{mL}$ oral suspension without thickening agent and the second was Placebo control sample, i.e., the thickening agent (weighed as per Table 2) plus $2 \mathrm{~g}$ of water instead of the Riluzole $5 \mathrm{mg} / \mathrm{mL}$ oral suspension.

\subsubsection{Determination of Riluzole Assay and Related Substances by HPLC}

Analyses have been performed by means of an Agilent 1100 Series HPLC Value System (AgilentTechnologies, Santa Clara, CA, USA) equipped with UV diode array detector. The following chromatographic conditions were used for Riluzole assay and related substances determination: column: $\mathrm{C} 18(100 \mathrm{~mm} \times 3.0 \mathrm{~mm}, 2.5 \mu \mathrm{m})$; detection wavelength: $225 \mathrm{~nm}$; temperature: $55{ }^{\circ} \mathrm{C}$; elution mode: gradient (mobile phase Solvent A: 0.1\% Trifluoroacetic in Water; Solvent B: 0.1\% Trifluoroacetic in Acetonitrile), run time: about $25 \mathrm{~min}$; concentration of Riluzole assay standard solution $\approx 80 \mu \mathrm{g} / \mathrm{mL}$; concentration of Riluzole related substances standard solution $\approx 0.4 \mu \mathrm{g} / \mathrm{mL}$; reference standard: Riluzole USP reference standard; injection volume: $4 \mu \mathrm{L}$ for Riluzole assay and $25 \mu \mathrm{L}$ for related substances determination. The method was validated as per ICH Q2 (R1) guideline. Absence of thickening agents' interference was also evaluated.

\subsubsection{Determination of Appearance and $\mathrm{pH}$ of Riluzole $5 \mathrm{mg} / \mathrm{mL}$ Oral Suspension-Thickener Mixtures}

These samples were prepared according to the compositions of Table 2 and the procedure reported above (obviously, without adding the dilution solvent), with the only difference that double amount of each mixture was prepared to allow for a sufficient testing amount. Appearance and $\mathrm{pH}$ were evaluated immediately after preparation and after a 2-h rest at room temperature. Control samples of both Riluzole $5 \mathrm{mg} / \mathrm{mL}$ oral suspension alone and Placebo were also prepared. Appearance of Riluzole $5 \mathrm{mg} / \mathrm{mL}$ oral suspension-thickener mixtures was determined by visual observation of the sample. $\mathrm{pH}$ of Riluzole $5 \mathrm{mg} / \mathrm{mL}$ oral suspension-thickener mixtures was determined by means of a calibrated pH-meter Basic 20 (Crison Instruments S.A., Spain).

\section{Results}

\subsection{IDDSI Flow Test Results}

Results are summarized in Tables 3 and 4 . For both lots of Riluzole $5 \mathrm{mg} / \mathrm{mL}$ oral suspension tested, on average the volume of liquid $(\mathrm{mL})$ remaining into the syringe after $10 \mathrm{~s}$ was corresponding to the level 2 of the IDDSI flow test (Drink Testing Methods), i.e., the "mildly thick" IDDSI descriptor [21]. The test was performed on two different batches of suspension, one development lot and one commercial lot thus providing a certain grade of robustness of the suspension thickness. 
Table 3. Riluzole $5 \mathrm{mg} / \mathrm{mL}$ oral suspension (lot 1521601): IDDSI Flow Test.

\begin{tabular}{|c|c|c|c|c|c|c|}
\hline \multirow{2}{*}{ Syringe Type } & \multirow{2}{*}{ Syringe $\mathbf{n}^{\circ}$} & \multirow{2}{*}{ Replicate $n^{\circ}$} & \multicolumn{4}{|c|}{$\begin{array}{l}\text { Riluzole } 5 \text { mg/mL Oral Suspension Lot } 1521601 \\
\text { (Development Lot) }\end{array}$} \\
\hline & & & \multicolumn{2}{|c|}{ Operator $\mathbf{n}^{\circ} \mathbf{1}$} & \multicolumn{2}{|c|}{ Operator $n^{\circ} 2$} \\
\hline \multirow{6}{*}{$\begin{array}{l}\text { BD Plastipak } \\
\qquad 10 \mathrm{~mL}^{\mathrm{TM}}\end{array}$} & \multirow{2}{*}{ (1) } & 1 & $4.0-4.5 \mathrm{~mL}$ & 2 & $4.0-4.5 \mathrm{~mL}$ & 2 \\
\hline & & 3 & $4.0-4.5 \mathrm{~mL}$ & 2 & $4.0-4.5 \mathrm{~mL}$ & 2 \\
\hline & \multirow{3}{*}{ (2) } & 1 & $5.0-5.5 \mathrm{~mL}$ & 2 & $4.5-5.0 \mathrm{~mL}$ & 2 \\
\hline & & 2 & $5.0-5.5 \mathrm{~mL}$ & 2 & $4.5-5.0 \mathrm{~mL}$ & 2 \\
\hline & & 3 & $5.0-5.5 \mathrm{~mL}$ & 2 & $4.5-5.0 \mathrm{~mL}$ & 2 \\
\hline & (3) & 1 & $4.0-4.5 \mathrm{~mL}$ & 2 & $3.5-4.0 \mathrm{~mL}$ & 1 \\
\hline
\end{tabular}

Notes: ${ }^{(*)}$ BD Plastipak ${ }^{\mathrm{TM}} 10 \mathrm{~mL}$ Luer tip syringe; Graduation: $0.5 \mathrm{~mL} ; 10 \mathrm{~mL}$ graduation scale length: $61.5 \mathrm{~mm}$, code REF 308027, lot 1207157, sterile single-use hypodermic syringe, equipped with a $21 \mathrm{GA} 11 / 2$ IN needle and a plunger that are removed prior to use the syringe for the IDDSI flow test, ${ }^{(* *)}$ rounded to the nearest unit value.

Table 4. Riluzole $5 \mathrm{mg} / \mathrm{mL}$ oral suspension (lot 16100): IDDSI Flow Test.

\begin{tabular}{|c|c|c|c|c|c|c|}
\hline \multirow{2}{*}{ Syringe Type } & \multirow{2}{*}{ Syringe $\mathbf{n}^{\circ}$} & \multirow{2}{*}{ Replicate $\mathbf{n}^{\circ}$} & \multicolumn{4}{|c|}{$\begin{array}{c}\text { Riluzole } 5 \mathrm{mg} / \mathrm{mL} \text { Oral Suspension Lot 16,100 } \\
\text { (Commercial Lot) }\end{array}$} \\
\hline & & & \multicolumn{2}{|c|}{ 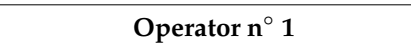 } & \multicolumn{2}{|c|}{ 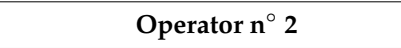 } \\
\hline \multirow{6}{*}{$\begin{array}{l}\text { BD Plastipak }{ }^{\mathrm{TM}} \\
10 \mathrm{~mL}^{(*)}\end{array}$} & \multirow{2}{*}{ (1) } & 1 & $5.5-6.0 \mathrm{~mL}$ & 2 & $5.5-6.0 \mathrm{~mL}$ & 2 \\
\hline & & 3 & $5.5-6.0 \mathrm{~mL}$ & 2 & $5.5-6.0 \mathrm{~mL}$ & 2 \\
\hline & \multirow{3}{*}{ (2) } & 1 & $6.5-7.0 \mathrm{~mL}$ & 2 & $5.0-5.5 \mathrm{~mL}$ & 2 \\
\hline & & 2 & $6.5-7.0 \mathrm{~mL}$ & 2 & $5.0-5.5 \mathrm{~mL}$ & 2 \\
\hline & & 3 & $6.5-7.0 \mathrm{~mL}$ & 2 & $6.0-6.5 \mathrm{~mL}$ & 2 \\
\hline & (3) & 1 & $5.5-6.0 \mathrm{~mL}$ & 2 & $5.0-5.5 \mathrm{~mL}$ & 2 \\
\hline
\end{tabular}

Notes: (*) BD Plastipak ${ }^{\mathrm{TM}} 10 \mathrm{~mL}$ Luer tip syringe; Graduation: $0.5 \mathrm{~mL} ; 10 \mathrm{~mL}$ graduation scale length: $61.5 \mathrm{~mm}$, code REF 308027, lot 1207157, sterile single-use hypodermic syringe, equipped with a 21GA 11/2 IN needle and a plunger that are removed prior to use the syringe for the IDDSI flow test, ${ }^{(* *)}$ rounded to the nearest unit value.

\subsection{HPLC Results: Riluzole Assay of Riluzole $5 \mathrm{mg} / \mathrm{mL}$ Oral Suspension-Thickener Mixtures}

Results are summarized in Table 5. System suitability test was run with five replicate injections of the Riluzole standard solution for Riluzole assay. The Relative Standard Deviation (RSD) was $0.13 \%$ (acceptance criterion RSD $\leq 2.0 \%$ ). All assays met the requirements (acceptance criterion was $4.50-5.50 \mathrm{mg} / \mathrm{mL}$ ) with no significant differences between samples at time zero and samples after $2 \mathrm{~h}$. Results were also similar to those of Riluzole $5 \mathrm{mg} / \mathrm{mL}$ oral suspension alone (control sample). None of the chromatograms of the Placebo control samples presented peaks at the same retention time of Riluzole, thus showing no interference of the thickeners. 
Table 5. Riluzole HPLC Assay Results.

\begin{tabular}{|c|c|c|c|}
\hline Sample & & $\begin{array}{c}\text { Riluzole Individual } \\
\text { Assay mg/mL (\% 1.c.) }\end{array}$ & $\begin{array}{l}\text { Riluzole Average Assay } \\
\text { mg/mL (\% l.c.) }\end{array}$ \\
\hline \multirow{2}{*}{$\begin{array}{l}\text { Control (Riluzole } 5 \mathrm{mg} / \mathrm{mL} \\
\text { oral suspension) }\end{array}$} & $\begin{array}{l}\text { Control- } \\
\text { sample } 1\end{array}$ & $4.96(99.2)$ & \multirow{2}{*}{4.99 (99.8) } \\
\hline & $\begin{array}{l}\text { Control- } \\
\text { sample } 2\end{array}$ & $5.01(100.2)$ & \\
\hline \multirow{4}{*}{$\begin{array}{l}\text { A: Nutilis Powder-Riluzole } \\
5 \mathrm{mg} / \mathrm{mL} \text { oral suspension } \\
\text { mixture }\end{array}$} & $\begin{array}{l}\text { Time } 0 \text { - } \\
\text { sample } 1\end{array}$ & 4.93 (98.6) & \multirow{2}{*}{4.97 (99.4) } \\
\hline & $\begin{array}{l}\text { Time } 0- \\
\text { sample } 2\end{array}$ & $5.00(100.0)$ & \\
\hline & $\begin{array}{l}\text { After } 2 \mathrm{~h}- \\
\text { sample } 1\end{array}$ & 5.06 (101.2) & \multirow{2}{*}{$5.06(101.2)$} \\
\hline & $\begin{array}{l}\text { After } 2 \mathrm{~h}- \\
\text { sample } 2\end{array}$ & 5.05 (101.0) & \\
\hline \multirow{4}{*}{$\begin{array}{l}\text { B: Nutilis Clear-Riluzole } \\
5 \mathrm{mg} / \mathrm{mL} \text { oral suspension } \\
\text { mixture }\end{array}$} & $\begin{array}{l}\text { Time } 0 \text { - } \\
\text { sample } 1\end{array}$ & $5.12(102.4)$ & \multirow{2}{*}{$5.11(102.2)$} \\
\hline & $\begin{array}{l}\text { Time } 0- \\
\text { sample } 2\end{array}$ & $5.10(102.0)$ & \\
\hline & $\begin{array}{l}\text { After } 2 \mathrm{~h}- \\
\text { sample } 1\end{array}$ & $5.11(102.2)$ & \multirow{2}{*}{$5.12(102.4)$} \\
\hline & $\begin{array}{l}\text { After } 2 \mathrm{~h}- \\
\text { sample } 2\end{array}$ & 5.13 (102.6) & \\
\hline \multirow{4}{*}{$\begin{array}{c}\text { C: RESOURCE }{ }^{\circledR} \\
\text { ThickenUp }{ }^{\mathrm{TM}}-\text { Riluzole } \\
5 \mathrm{mg} / \mathrm{mL} \text { oral suspension } \\
\text { mixture }\end{array}$} & $\begin{array}{l}\text { Time } 0- \\
\text { sample } 1\end{array}$ & $4.89(97.8)$ & \multirow{2}{*}{4.93 (98.6) } \\
\hline & $\begin{array}{l}\text { Time } 0- \\
\text { sample } 2\end{array}$ & $4.96(99.2)$ & \\
\hline & $\begin{array}{l}\text { After } 2 \mathrm{~h}- \\
\text { sample } 1\end{array}$ & $4.94(98.8)$ & \multirow{2}{*}{$4.96(99.2)$} \\
\hline & $\begin{array}{l}\text { After } 2 \mathrm{~h}- \\
\text { sample } 2\end{array}$ & 4.98 (99.6) & \\
\hline \multirow{4}{*}{$\begin{array}{c}\text { D: Fresubin }{ }^{\circledR} \text { Clear } \\
\text { Thickener-Riluzole } \\
5 \mathrm{mg} / \mathrm{mL} \text { oral suspension } \\
\text { mixture }\end{array}$} & $\begin{array}{l}\text { Time } 0- \\
\text { sample } 1\end{array}$ & 4.99 (99.8) & \multirow{2}{*}{$5.03(100.7)$} \\
\hline & $\begin{array}{l}\text { Time } 0- \\
\text { sample } 2\end{array}$ & 5.07 (101.4) & \\
\hline & $\begin{array}{l}\text { After } 2 \mathrm{~h}- \\
\text { sample } 1\end{array}$ & 4.93 (98.6) & \multirow{2}{*}{4.95 (98.9) } \\
\hline & $\begin{array}{l}\text { After } 2 \mathrm{~h}- \\
\text { sample } 2\end{array}$ & $4.96(99.2)$ & \\
\hline \multirow{4}{*}{$\begin{array}{c}\text { E: THICK \& EASY }{ }^{\mathrm{TM}} \text { Instant } \\
\text { Food Thickener-Riluzole } \\
5 \mathrm{mg} / \mathrm{mL} \text { oral suspension } \\
\text { mixture }\end{array}$} & $\begin{array}{l}\text { Time } 0- \\
\text { sample } 1\end{array}$ & $4.96(99.2)$ & \multirow{2}{*}{4.97 (99.4) } \\
\hline & $\begin{array}{l}\text { Time } 0- \\
\text { sample } 2\end{array}$ & $4.97(99.4)$ & \\
\hline & $\begin{array}{l}\text { After } 2 \mathrm{~h}- \\
\text { sample } 1\end{array}$ & 5.03 (100.6) & \multirow{2}{*}{$5.01(100.2)$} \\
\hline & $\begin{array}{l}\text { After } 2 \mathrm{~h}- \\
\text { sample } 2\end{array}$ & 4.98 (99.6) & \\
\hline
\end{tabular}

Notes: 1.c.: label concentration; ${ }^{(*)}$ acceptance criteria: $4.50-5.50 \mathrm{mg} / \mathrm{mL}(90-110 \%$ 1.c.). 
3.3. HPLC Results: Riluzole-Related Substances of Riluzole $5 \mathrm{mg} / \mathrm{mL}$ Oral Suspension-Thickener Mixtures

Results are summarized in Table 5. Comparison of chromatograms relevant to Riluzole $5 \mathrm{mg} / \mathrm{mL}$ oral suspension/Thickener (A-B-C-D-E) mixtures (after $2 \mathrm{~h}$ ); Riluzole $5 \mathrm{mg} / \mathrm{mL}$ oral suspension "as is" and Placebo control samples (Thickener A-B-C-D-E as is after $2 \mathrm{~h}$ ) is summarized in Figures 1-5. System suitability test was run with five replicate injections of the Riluzole standard solution for related substances. The RSD was $0.34 \%$ (acceptance criterion RSD $\leq 2.0 \%$ ). No peaks at different retention time than of Riluzole were detected, except for samples B and D, both at time zero and after $2 \mathrm{~h}$. However, the same peaks were also present in the chromatogram of Placebo control samples. Therefore, these unknown peaks were not attributable to Riluzole-related substances.
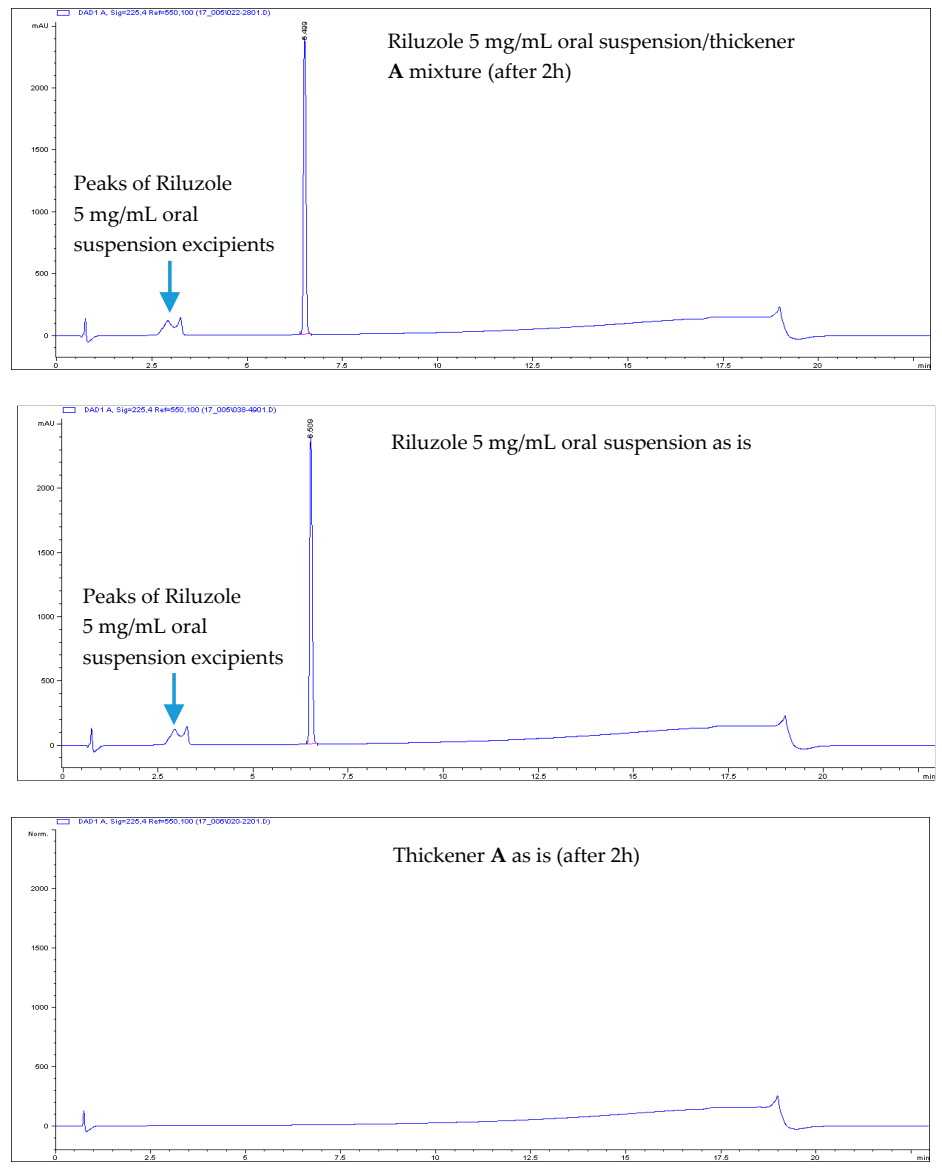

Figure 1. Comparison of chromatograms: Riluzole $5 \mathrm{mg} / \mathrm{mL}$ oral suspension/thickener A mixture (after $2 \mathrm{~h}$ ); Riluzole $5 \mathrm{mg} / \mathrm{mL}$ oral suspension as is and Thickener $\mathrm{A}$ as is (after $2 \mathrm{~h}$ ). 

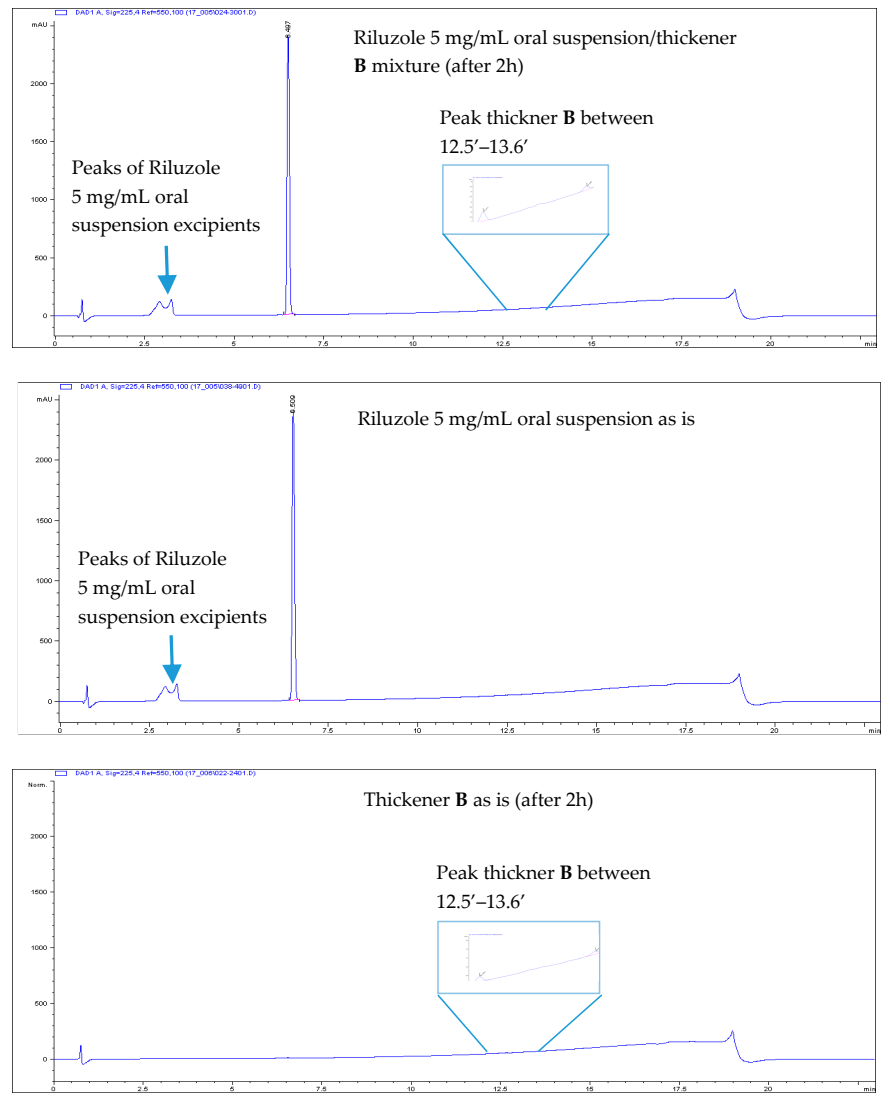

Figure 2. Comparison of chromatograms: Riluzole $5 \mathrm{mg} / \mathrm{mL}$ oral suspension/thickener B mixture (after $2 \mathrm{~h}$ ); Riluzole $5 \mathrm{mg} / \mathrm{mL}$ oral suspension as is and Thickener B as is (after $2 \mathrm{~h}$ ).
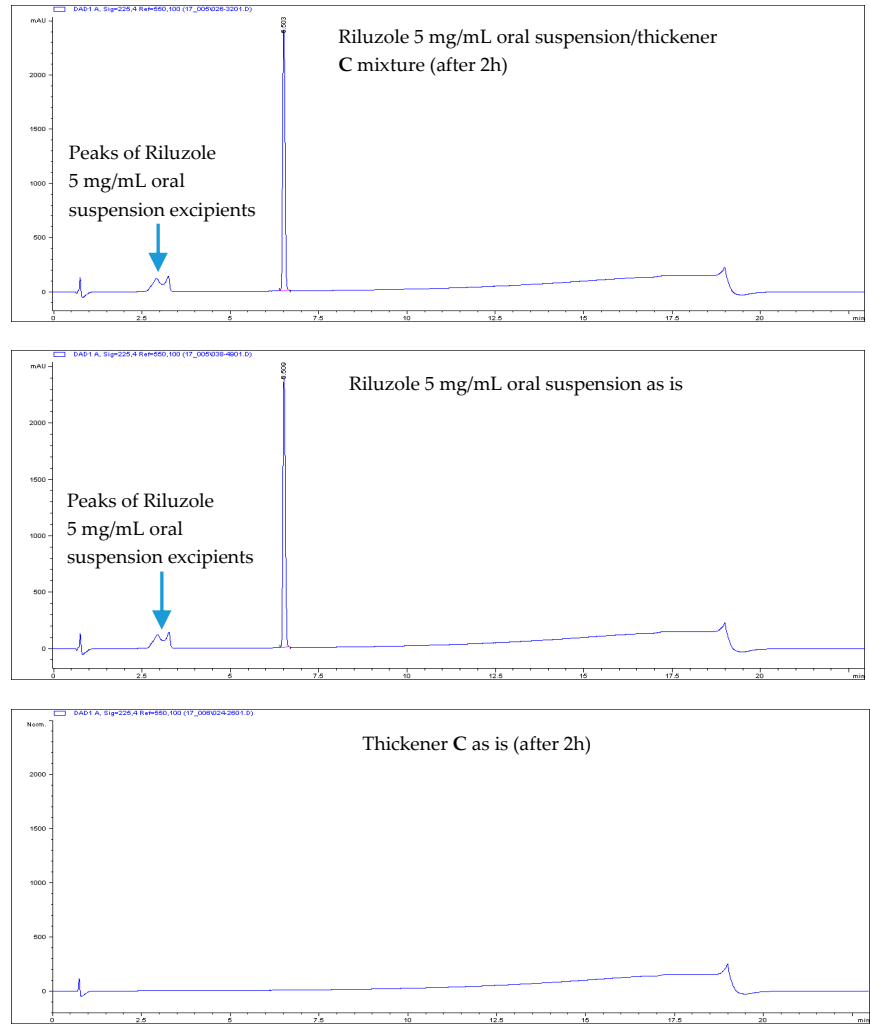

Figure 3. Comparison of chromatograms: Riluzole $5 \mathrm{mg} / \mathrm{mL}$ oral suspension/thickener $\mathrm{C}$ mixture (after $2 \mathrm{~h}$ ); Riluzole $5 \mathrm{mg} / \mathrm{mL}$ oral suspension as is and Thickener $\mathrm{C}$ as is (after $2 \mathrm{~h}$ ). 

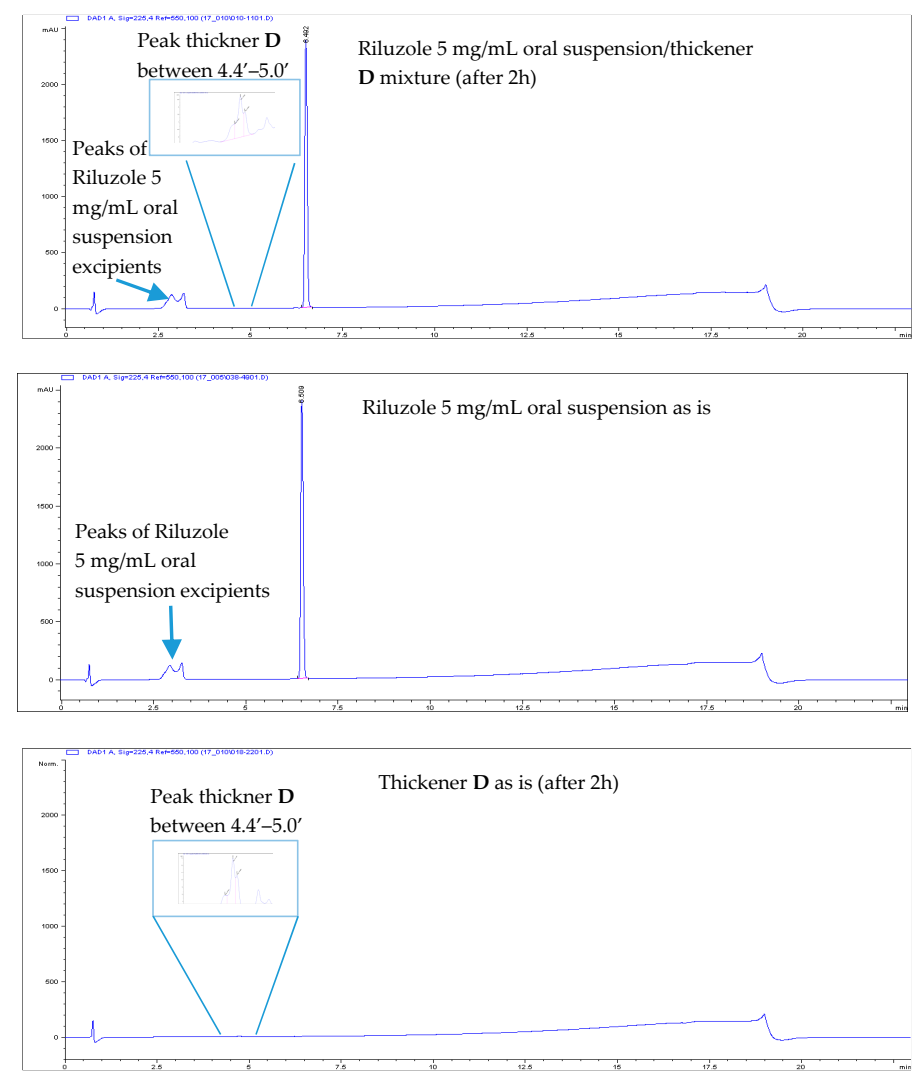

Figure 4. Comparison of chromatograms: Riluzole $5 \mathrm{mg} / \mathrm{mL}$ oral suspension/thickener D mixture (after $2 \mathrm{~h}$ ); Riluzole $5 \mathrm{mg} / \mathrm{mL}$ oral suspension as is and Thickener D as is (after $2 \mathrm{~h}$ ).
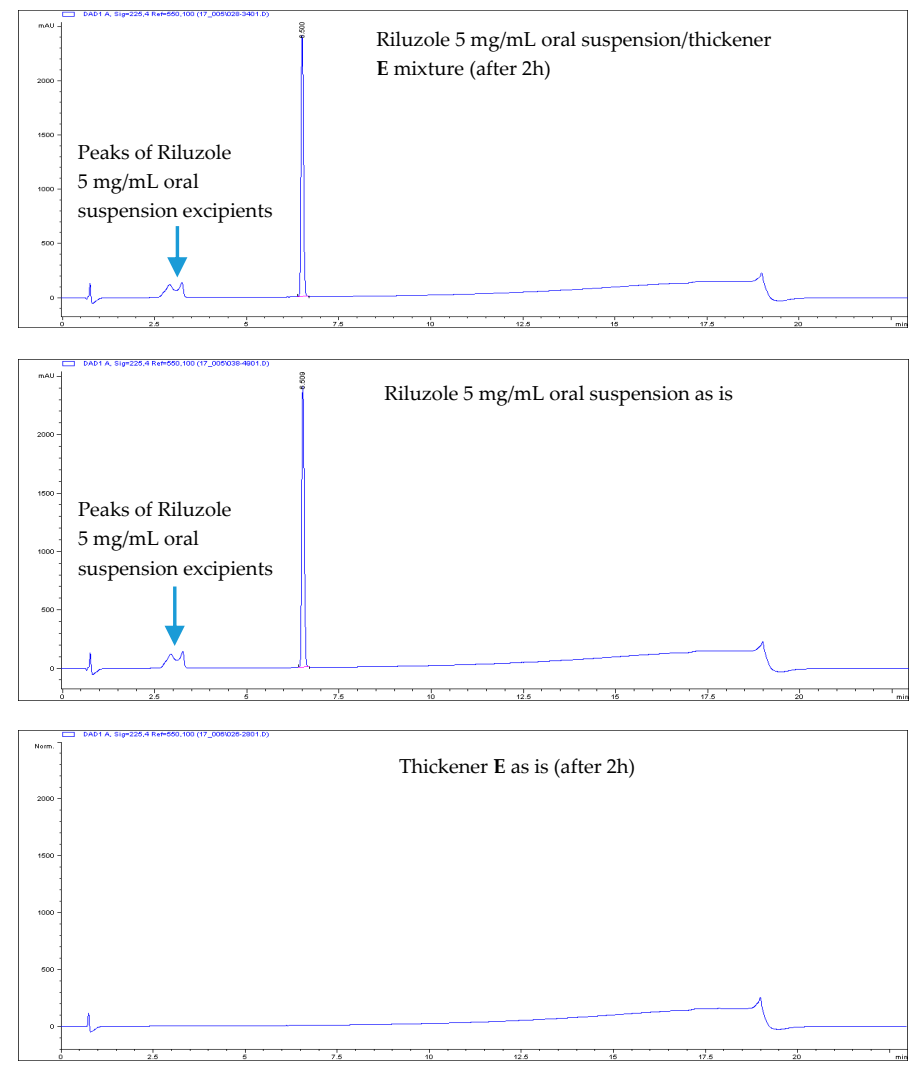

Figure 5. Comparison of chromatograms: Riluzole $5 \mathrm{mg} / \mathrm{mL}$ oral suspension/thickener E mixture (after $2 \mathrm{~h}$ ); Riluzole $5 \mathrm{mg} / \mathrm{mL}$ oral suspension as is and Thickener $\mathrm{E}$ as is (after $2 \mathrm{~h}$ ). 


\subsection{Appearance and $\mathrm{pH}$ of Riluzole $5 \mathrm{mg} / \mathrm{mL}$ Oral Suspension-Thickener Mixtures and Placebo Control Samples}

Results are summarized in Table 6. Appearance/colour recorded based upon visual observation of the sample at initial time and after two $h$ are compared: appearance/colour was the same for all mixtures both at time zero and after $2 \mathrm{~h}$, i.e., no incompatibility could be visually observed between thickeners and Riluzole oral suspension.

Table 6. Appearance and pH Results.

\begin{tabular}{|c|c|c|c|c|}
\hline \multirow{2}{*}{ Sample } & \multicolumn{2}{|l|}{ Initial (time 0) } & \multicolumn{2}{|l|}{ After $2 \mathrm{~h}$} \\
\hline & Appearance & $\mathrm{pH}$ & Appearance & $\mathrm{pH}$ \\
\hline $\begin{array}{c}\text { Control } \\
\text { (Riluzole } 5 \mathrm{mg} / \mathrm{mL} \text { oral suspension) }\end{array}$ & $\begin{array}{l}\text { Slightly brown, opaque } \\
\text { homogenous suspension }\end{array}$ & 8.19 & $\begin{array}{l}\text { Slightly brown, opaque } \\
\text { homogenous suspension }\end{array}$ & 8.18 \\
\hline $\begin{array}{l}\text { A: Nutilis Powder-Riluzole } 5 \mathrm{mg} / \mathrm{mL} \\
\quad \text { oral suspension mixture }\end{array}$ & $\begin{array}{l}\text { Slightly brown, opaque } \\
\text { homogenous mixture }\end{array}$ & 8.02 & $\begin{array}{l}\text { Slightly brown, opaque } \\
\text { homogenous mixture }\end{array}$ & 7.99 \\
\hline $\begin{array}{c}\text { B: Nutilis Clear-Riluzole } 5 \mathrm{mg} / \mathrm{mL} \\
\text { oral suspension mixture }\end{array}$ & $\begin{array}{l}\text { Slightly brown, opaque } \\
\text { homogenous mixture }\end{array}$ & 8.01 & $\begin{array}{l}\text { Slightly brown, opaque } \\
\text { homogenous mixture }\end{array}$ & 7.86 \\
\hline $\begin{array}{c}\text { C: RESOURCE }{ }^{\circledR} \\
\text { ThickenUp }{ }^{\mathrm{TM}} \text { _Riluzole } 5 \mathrm{mg} / \mathrm{mL} \text { oral } \\
\text { suspension mixture }\end{array}$ & $\begin{array}{l}\text { Slightly brown, opaque } \\
\text { homogenous mixture }\end{array}$ & 7.99 & $\begin{array}{l}\text { Slightly brown, opaque } \\
\text { homogenous mixture }\end{array}$ & 8.03 \\
\hline $\begin{array}{c}\text { D: Fresubin }{ }^{\circledR} \text { Clear } \\
\text { Thickener-Riluzole } 5 \mathrm{mg} / \mathrm{mL} \text { oral } \\
\text { suspension mixture }\end{array}$ & $\begin{array}{l}\text { Slightly brown, opaque } \\
\text { homogenous mixture }\end{array}$ & 7.21 & $\begin{array}{l}\text { Slightly brown, opaque } \\
\text { homogenous mixture }\end{array}$ & 6.40 \\
\hline $\begin{array}{l}\text { E: THICK \& EASY }{ }^{\mathrm{TM}} \text { Instant Food } \\
\text { Thickener-Riluzole } 5 \mathrm{mg} / \mathrm{mL} \text { oral } \\
\text { suspension mixture }\end{array}$ & $\begin{array}{l}\text { Slightly brown, opaque } \\
\text { homogenous mixture }\end{array}$ & 8.05 & $\begin{array}{l}\text { Slightly brown, opaque } \\
\text { homogenous mixture }\end{array}$ & 7.93 \\
\hline
\end{tabular}

Notes: Placebo control samples $\mathrm{pH}$ values were all in the 5.90 to 6.40 range both at initial time and after $2 \mathrm{~h}$.

No practical differences have been noticed between $\mathrm{pH}$ values of Riluzole $5 \mathrm{mg} / \mathrm{mL}$ oral suspension alone and Riluzole $5 \mathrm{mg} / \mathrm{mL}$ oral suspension-thickener mixtures both at time zero and after $2 \mathrm{~h}$, except for sample D, which exhibited a lower value at time zero (7.21 vs. 8.19), which further decreased to 6.40 after $2 \mathrm{~h}$. This may be due to some buffering/pH adjusting property of some component of the relevant thickener, however this $\mathrm{pH}$ decrease resulted to have no impact on Riluzole chemical stability.

\section{Discussion}

One objective of this work was to evaluate the texture of Riluzole $5 \mathrm{mg} / \mathrm{mL}$ oral suspension according to the IDDSI flow test. Results of this experiment indicated that Riluzole $5 \mathrm{mg} / \mathrm{mL}$ oral suspension would basically fall under the "mildly thick" IDDSI descriptor [21]. This is an important feature because thick fluids facilitate a safer swallow in patients with dysphagia. In fact, according to the IDDSI descriptors physiological rationale for this level of thickness, if thin drinks flow too fast to be controlled safely, "mildly thick" liquids will flow at a slightly slower rate and may be suitable if tongue control is slightly reduced.

Liquids are the preferred method of administering medications to patients with swallowing difficulties. According to the expert group guidelines for the management of drug administration to patients with swallowing issues [9], SODF (solid oral dosage forms) manipulation is the last option after thorough considerations and consultations, while, as already pointed out, availability of a liquid or dispersible product is the first option. When a patient cannot take oral solid dosage forms due to dysphagia, the APSM (Association of Pharmaceutical Specials Manufacturers) recommends to make sure that there is no licensed alternative in dispersible or oral liquid form, before modification of SODF [24].

Many papers recognize the potential consequences of manipulating a medicinal product (e.g., crushing tablets and opening capsules and/or their mixing with food and beverages) such as instability, local irritation, modification of drug performance, occupational health and safety issues, unacceptable taste. Also, it should be recognized that altering the dosage form of a licensed medicine renders it unlicensed [25-28]. Many healthcare professionals assume that patients with dysphagia 
need to be prescribed liquid. However, this is a misconception [25], because some thin medicines can increase the risk of coughing and aspiration. To facilitate a safer swallow and slow oesophageal transit, medication may need to be formulated as thicker fluid as it is the case of Riluzole $5 \mathrm{mg} / \mathrm{mL}$ oral suspension, whose texture not only ensure its physical stability and an easy withdrawal/administration but also may facilitate swallowing.

Another objective of this work was to evaluate the compatibility of the commercial Riluzole $5 \mathrm{mg} / \mathrm{mL}$ oral suspension with some of the most common food thickeners available on the market. To this aim, Riluzole suspension was intimately mixed with different thickeners. Mixtures were then evaluated for appearance, $\mathrm{pH}$, Riluzole assay and Riluzole related substances immediately after preparation and after two $h$ at room temperature. In order to establish worst case conditions for incompatibilities, the highest dose of each thickener was used, based on the instructions for use of each of them. All results met the acceptance criteria, in particular:

- All Riluzole HPLC assays were within the $90-110 \%$ of the label concentration, both at initial time and after two h.

- No related substances were detected, both at initial time and after two $h$. The only peaks detected in the HPLC chromatograms were unequivocally attributed to Placebo (i.e., the thickener itself).

- No practical $\mathrm{pH}$ differences were observed between Riluzole $5 \mathrm{mg} / \mathrm{mL}$ oral suspension alone and mixed with the thickeners, except for the Fresubin ${ }^{\circledR}$ Clear Thickener sample, for which a $\mathrm{pH}$ decrease was observed (from 7.2 to 6.4), however this $\mathrm{pH}$ decrease resulted to have no impact on Riluzole chemical stability.

- No significant changes in appearance were observed after two h.

Thus, in conclusion, Riluzole $5 \mathrm{mg} / \mathrm{mL}$ oral suspension resulted to be compatible with all the marketed thickeners tested.

For ALS patients the use of thickened liquid is a common compensatory strategy to improve swallow safety. A specific subset of dysphagic patients who swallow puree without aspiration but aspirated thin liquid demonstrated 100\% successful swallowing of both nectar- and honey-like thickened liquids [29].

\section{Conclusions}

Riluzole $5 \mathrm{mg} / \mathrm{mL}$ suspension is the only licensed liquid medicine to treat ALS orally. The suspension is administered by means of the graduated oral dosing syringe included in the medicine package. Its concentration $(5 \mathrm{mg} / \mathrm{mL})$ is consistent with a small and easy to measure volume $(10 \mathrm{~mL})$ to deliver the prescribed 50-mg dose twice daily. In this experimental work we have evaluated the texture of Riluzole $5 \mathrm{mg} / \mathrm{mL}$ oral suspension according to the IDDSI flow test as well as its compatibility with some of the most common food thickeners available on the market. Results of this experiment indicated that Riluzole $5 \mathrm{mg} / \mathrm{mL}$ oral suspension would basically fall under the "mildly thick" IDDSI descriptor, since the average volume of liquid $(\mathrm{mL})$ remaining into the syringe after $10 \mathrm{~s}$ was corresponding to the level 2 of the IDDSI flow test, as well as that Riluzole $5 \mathrm{mg} / \mathrm{mL}$ oral suspension was compatible with all the marketed thickeners tested.

These are important features for ALS patients that develop dysphagia, as, regardless of whether the onset is "bulbar" or "limb", the use of thickened liquid is a common compensatory strategy to improve swallow safety.

Author Contributions: Conceptualization D.B. and R.A and G.C; Investigation and original draft preparation, D.B.; supervision: R.A.; writing — review and editing, G.C. All authors have read and agreed to the published version of the manuscript.

Funding: This research received no external funding.

Conflicts of Interest: The study was performed c/o the Pharmaceutical Technology Laboratory of Italfarmaco SpA. The authors (R. Artico, D. Barbareschi and G. Colombo) are employee of Italfarmaco SpA. Italfarmaco SpA (and its affiliates) is the Marketing Authorization Holder of Riluzole $50 \mathrm{mg} / 10 \mathrm{~mL}(5 \mathrm{mg} / \mathrm{mL})$ oral suspension. 


\section{References}

1. ALS Therapy Development Institute. What Is ALS? Available online: https:/www.als.net/what-is-als/ (accessed on 14 February 2020).

2. Onesti, E.; Schettino, I.; Gori, M.C.; Frasca, V.; Ceccanti, M.; Cambieri, C.; Ruoppolo, G.; Inghilleri, M. Dysphagia in amytrophic lateral sclerosis: Impact on patient behavior, diet adaptation, and Riluzole management. Front. Neurol. 2017, 8, 94. [CrossRef] [PubMed]

3. Kühnlein, P.; Gdynia, H.J.; Sperfeld, A.D.; Lindner-Pfleghar, B.; Ludolph, A.C.; Prosiegel, M.; Riecker, A. Diagnosis and treatment of bulbar symptoms in amyotrophic lateral sclerosis. Nat. Clin. Prac. Neurol. 2008, 4, 366-374. [CrossRef] [PubMed]

4. Boccardi, V.; Ruggiero, C.; Patriti, A.; Marano, L. Diagnostic Assessment and Management of Dysphagia in Patients with Alzheimer's Disease. J. Alzheimer's Dis. 2016, 50, 947-955. [CrossRef] [PubMed]

5. Keating, G.M. Riluzole oral suspension in amyotrophic lateral sclerosis: A guide to its use. Drugs Ther. Perspect. 2016, 32, 282-286. [CrossRef]

6. Healtcare-Disphagia and Dementia. Available online: https://www.premierfoodservice.co.uk/downloads (accessed on 14 February 2020).

7. Hinchcliffe, M.; Smith, A. Riluzole: Real-world evidence supports significant extension of median survival times in patients with amyotrophic lateral sclerosis. Degener. Neurol. Neuromuscul. Dis. 2017, 7, 61-70. [CrossRef] [PubMed]

8. Wright, D.; Tomlin, S. How to help if a patient can't swallow. Pharm. J. 2011, 286, 271-274.

9. Wright, D.; Chapman, N.; Miah, F.M.; Greenwall, R.; Griffith, R.; Guyon, A.; Merriman, H. Guideline on the Medication Management of Adults with Swallowing Difficulties; Medenium Group Publishing Ltd.: Berkhamsted, UK, 2015.

10. Bensimon, G.; Lacomblez, L.; Meininger, V. The ALS/Riluzole Study Group A Controlled Trial of Riluzole in Amyotrophic Lateral Sclerosis. N. Engl. J. Med. 1994, 330, 585-591. [CrossRef] [PubMed]

11. Georgoulopoulou, E.; Fini, N.; Vinceti, M.; Monelli, M.; Vacondio, P.; Bianconi, G.; Sola, P.; Paolo Nichelli, P.; Mandrioli, J. The impact of clinical factors, riluzole and therapeutic interventions on ALS survival: A population based study in Modena, Italy. Amyotroph. Lateral Scler. Front. Degener. 2013, 14, 338-345. [CrossRef] [PubMed]

12. Andersen, P.M.; Abrahams, S.; Borasio, G.D.; de Carvalho, M.; Chio, A.; van Damme, P.; Hardiman, O.; Kollewe, K.; Morrison, K.E.; Petri, S.; et al. EFNS guidelines on the clinical management of amyotrophic lateral sclerosis (MALS)—Revised report of an EFNS task force. Eur. J. Neurol. 2012, 19, 360-375. [CrossRef] [PubMed]

13. Radunović, A.; Mitsumoto, H.; Leigh, P.N. Clinical care of patients with amyotrophic lateral sclerosis. Lancet Neurol. 2007, 6, 913-925. [CrossRef]

14. Mandrioli, J.; Malerba, S.A.; Beghi, E.; Fini, N.; Fasano, A.; Zucchi, E.; de Pasqua, S.; Guidi, C.; Terlizzi, E.; Sette, E.; et al. Riluzole and other prognostic factors in ALS: A population-based registry study in Italy. J. Neurol. 2018, 265, 817-827. [CrossRef] [PubMed]

15. Dyer, A.M.; Smith, A. Riluzole $5 \mathrm{mg} / \mathrm{mL}$ oral suspension: For optimized drug delivery in amyotrophic lateral sclerosis. Drug Des. Dev. Ther. 2017, 11, 59-64. [CrossRef] [PubMed]

16. Sinko, P.J.; Singh, Y. Coarse Dispersions. Martin's Physical Pharmacy and Pharmaceutical Sciences, 6th ed.; Troy, D.B., Ed.; Lippincott Williams \& Wilkins: Baltimore, MD, USA, 2010; ISBN 978-0-7817-9766-5.

17. ALS News Today. FDA Approves Tiglutik ${ }^{\mathrm{TM}}$, Liquid Form of Riluzole, for ALS Patients. Available online: https://alsnewstoday.com/2018/09/07/fda-approves-tiglutik-an-oral-suspension-of-Riluzole-to-treatals/ (accessed on 14 February 2020).

18. Steele, C.M.; Alsanei, W.A.; Ayanikalath, S.; Ayanikalath, S.; Barbon, C.E.A.; Chen, J.; Cichero, J.A.Y.; Coutts, K.; Dantas, R.O.; Duivestein, J.; et al. The Influence of Food Texture and Liquid Consistency Modification on Swallowing Physiology and Function: A Systematic Review. Dysphagia 2015, 30, 2-26. [CrossRef] [PubMed]

19. Cichero, J.A.Y. Thickening agents used for dysphagia management: Effect on bioavailability of water, medication and feelings of satiety. Nutr. J. 2013, 12, 1-8. [CrossRef] [PubMed]

20. Barbon, C.E.A.; Steele, C.M. Thickened Liquids for Dysphagia Management: A Current Review of the Measurement of Liquid Flow. Curr. Phys. Med. Rehabil. Rep. 2018, 6, 220-226. [CrossRef] [PubMed] 
21. IDDSI. Complete IDDSI Framework Testing Methods. Available online: https://iddsi.org/Documents/ IDDSIFramework-TestingMethods.pdf (accessed on 14 February 2020).

22. BDA/RCSLT. National Descriptors for Texture Modification in Adults. Available online: https://www. findusfoodservices.se/content/SE/Special\%20Foods/Fakta\%20\&\%20forskning/Konsistensanpassad\% 20mat/TMF_National_descriptors_UK.pdf (accessed on 14 February 2020).

23. United Kingdom Adoption of IDDSI. Available online: https://www.bda.uk.com/resource/the-bdaannounces-adoption-of-the-international-dysphagia-diet-standardisation-initiative-iddsi-framework. html (accessed on 14 February 2020).

24. APSM (Association of Pharmaceutical Specials Manufacturers). Medicines Manipulation-Crushing, Opening or Splitting Tablets. Available online: http://www.apsm-uk.com/files/Crushing_tablets.pdf (accessed on 14 February 2020).

25. Barnett, N.; Parmar, P. How to tailoring medication formulations for patients with dysphagia. Pharm. J. 2016, 297. [CrossRef]

26. Stegemann, S.; Gosch, M.; Breitkreutz, J. Swallowing dysfunction and dysphagia is an unrecognized challenge for oral drug therapy. Int. J. Pharm. 2012, 430, 197-206. [CrossRef] [PubMed]

27. Royal Pharmaceutical Society. Pharmaceutical Issues when Crushing, Opening or Splitting Oral Dosage Forms. June 2011. Available online: https://www.rpharms.com/Portals/0/RPS\%20document\%20library/Open\% 20access/Support/toolkit/pharmaceuticalissuesdosageforms-\%282\%29.pdf (accessed on 14 February 2020).

28. Kelly, J.; Wright, D.; Wood, J. Medicine administration errors in patients with dysphagia in secondary care: A multi-centre observational study. J. Adv. Nurs. 2011, 67, 2615-2627. [CrossRef] [PubMed]

29. Leder, S.B.; Judson, B.L.; Sliwinski, E.; Madson, L. Promoting Safe Swallowing When Puree is Swallowed without Aspiration but Thin Liquid is Aspirated: Nectar is Enough: Original Article. Dysphagia 2013, 28, 58-62. [CrossRef] [PubMed]

(C) 2020 by the authors. Licensee MDPI, Basel, Switzerland. This article is an open access article distributed under the terms and conditions of the Creative Commons Attribution (CC BY) license (http://creativecommons.org/licenses/by/4.0/). 